\title{
EDUCATION, BUSINESS, AND INDUSTRY COMPETENCY STANDARD: A RESEARCH AND DEVELOPMENT STUDY
}

\author{
Thoat \\ Graduate School, Universitas Negeri Semarang, Semarang, Indonesia \\ Tri Joko Raharjo \\ Graduate School, Universitas Negeri Semarang, Semarang, Indonesia \\ Masrukhi \\ Graduate School, Universitas Negeri Semarang, Semarang, Indonesia \\ Erni Suharini \\ Graduate School, Universitas Negeri Semarang, Semarang, Indonesia
}

Article DOI: https://doi.org/10.36713/epra5961

\begin{abstract}
Education in Indonesia, especially in the vocational field, aims to develop students who can work directly after graduating from education are still unable to meet the desires and requirements of industry and business. This phenomenon is indicated by the low absorption of work and competencies that are not following the existing education curriculum. Vocational studies are still not in accordance with the competencies expected in industry and business. This research aims to create a formula through research and development research to create a model that can be applied by schools in designing industry and business-based curriculum in vocational schools. Several aspects need to be adopted from the field of industry and business, therefore they can be applied to the school curriculum when a student has taken vocational education, it is necessary to have a test from a professional standardization institution to ensure that the competencies needed are following what is expected. The results of this study can be used as a reference for forming a curriculum in vocational-based schools to be able to meet business and industry requirements.
\end{abstract}

KEYWORDS: Vocational, Education, Curriculum, Industry, Business.

\section{INTRODUCTION}

The essence of the aim of secondary level vocational education to prepare students, especially to work in certain fields. Vocational education plays an important role in labor supply because economic institutions require an educated and trained workforce. However, the workforce produced so far has not been able to answer the problem of the need for workers who meet the qualifications required by the field of work. There are still many job opportunities offered by the job market that have not been filled because existing education graduates are not absorbed by the job market (Fuller, 2015). The answer to this fact is that the quality of education graduates is still low due to the low quality of the learning process, especially in vocational high schools. According to Hanushek et al., (2017), one of the important challenges faced by schools, colleges, and universities is how to manage quality. This effort to improve and guarantee quality is a big job in the field of education. The government has set quality references that are used to achieve or fulfill the quality of education 
in educational units. The quality reference is the Indonesian National Education Standards and other standards agreed upon by community groups. National education standards are standards made by the government, while other standards are standards made by educational units and/or other institutions that are used as references by educational units (Norjannah, 2015). Other standards agreed upon by community groups are used after the SNP is fulfilled by the education unit according to the specificity of the path, level, and type of education.

Teaching factory is a development of the production unit, namely the application of partner industry systems in the existing production units in vocational education. The production unit is the development of the school business sector in addition to increasing school income which can be used in the maintenance of equipment, school operations, improving teacher welfare, increasing the capacity of educators and education personnel as well as providing real work experience for students. The implementation of the production unit itself has a legal basis, namely Indonesian Government Regulation No. 29 of 1990 which to prepare vocational high school students to become the workforce, vocational high schools can establish production units that operate professionally

Learning through teaching factory and industrial classes aims to develop the character and work ethic (discipline, responsibility, honesty, cooperation, leadership, etc.) needed by business and industry and improve the quality of learning outcomes rather than just providing competency (competency-based training) leading to learning that equips the ability to produce goods/services (production-based training).

The cooperative relationship between vocational education and industry in the teaching factory learning pattern or industrial class will have a positive impact on building a systematic and planned partnership mechanism based on a win-win solution bargaining position. The application of the teaching factory learning pattern is an interface between the field of vocational education and the industrial field hence that there are a check and balance of the education process at vocational education to maintain and maintain harmony (link and match) with the needs of the job market.

According to Zimmermann et al., (2013) efforts to improve the quality of vocational education are not only focused on improving the institution (institution/school) but must be accompanied by substantial modifications to the policy, curriculum, and teacher training. Hanafi (2012) argues that the application of the competency-based learning model has consequences for systemic improvement. Systemic reform components include: (1) the establishment of a challenging standard as a reference for what kind of abilities the graduates must master; (2) conformity between curriculum and learning, assessment and accountability, and teacher certification and professional development with new academic standards; and (3) changes (revamping) in the school governance structure, by providing greater autonomy in organizing learning programs at the local level.

Criticism of the failure of efforts to improve the quality of education. Because so far research has focused more on phenomena related to education, not on things that occur in the dynamics and learning process, research is needed to address problems that exist primarily inside education, namely research that is research-based problem solving (Wardoyo, 2015). Furthermore, according to Osler (2011), improving the quality of graduates can be achieved through the implementation of a systemic and holistic learning outcome assessment process. This study aims to find and develop an ideal education model for vocational high schools

\section{Competency-Based Training}

\section{LITERATURE REVIEW}

Competency-Based Training is a teaching process whose planning, implementation, and assessment refer to the mastery of student competencies. The purpose of this approach is so that the activities carried out in the teaching process refer to and direct students to achieve mastery of competencies that have been programmed together with the business field and the industrial field.

With this competency-based training approach, Ford \& Meyer (2015) argue learning, in essence, contains a set of competencies that students need to have through a process of learning activities which has the following characteristics: (1) Learning activities are the mastery of competencies by students; (2) The learning process must match the conditions in which the competence will be used; (3) Learning activities are individual (individualized instruction), there is no dependence between one student and other students; and (4) There should be an enrichment program for students who are faster and remedial programs for slower students.

Describing the abilities of a competent worker for a job includes identifying and listing the performances that a competent worker should display in a particular job. This process is also called occupational analysis (analysis of job tasks). This learning approach emphasizes the mastery of competencies according to determined standards, through learning activities that are designed and implemented in a structured manner and focus on students (learner-focused) through gradual completion of tasks/competencies (task-focused).

Therefore, Morris et al., (2013) state the implementation of learning with a competency-based training approach must meet the following requirements: (a) The curriculum must be developed referring to the competency standards set by the industry / professional association, and contain content that supports competency achievement; (b) Teaching modules / materials must be developed based on curriculum and 
competency standards, and be able to provide opportunities for students to take part in programs according to their own speed level; (c) The teacher or instructor must have the competence in their field; (d) Learners, have competencies in accordance with their fields; (e) Training activities are organized appropriately so that they can be carried out flexibly and provide fair treatment to students according to their potential; (f) Facilities must be adequate for all learners, both in terms of type, quantity and quality; (g) Institutional management needs to be developed in accordance with the spirit of reform; and (h) operational costs of education and training, adequate according to operational needs in achieving student competence.

Competency-based learning, in its implementation, not only emphasizes knowledge but also emphasizes the process and scientific attitude. Through assignments and performance, it is expected to be able to do scientific reasoning in the sense of thinking effectively in solving the problems at hand. Several forms of learning can be chosen in spurring students to achieve the expected competencies, such as the implementation of internships, industrial classes, teaching factories, and technopark. Hodge (2007) states that the teaching factory converts educational vehicles into (1) a challenging place for students to gain experience, (2) develop a sense of responsibility, (3) accountability, (4) behavioral attitudes, and (5) ) knowledge and skills for their contribution to society in the future.

The concept of learning in a real setting, thus bridging the potential gap between industry needs and knowledge acquired in educational institutions (Raharjo, 2005). Innovative learning technologies and production practices are concepts of educational methods that are oriented towards the management of human resource management in learning that can be in tune with the needs of the industrial field. Competency-based learning is a learning concept that emphasizes the development of the ability to perform tasks with certain standards so that the results can be felt by students in the form of mastery of a certain set of competencies (Bok et al., 2013; Brightwell \& Grant, 2013; Zhu et al., 2013). Competency-based learning is directed at developing the knowledge, understanding, abilities, values, attitudes, and interests of students so that they can do something in the form of skill, determination, and success with full responsibility (Koh et al., 2008).

\section{Partnership with Business or Industry}

Partnership in the field of education is one of nature, the absoluteness of education as the meaning and need for partnership in the field of human life as social beings (Benešová \& Tupa, 2017). In detail, partnerships and cooperation must be able to provide real facilitation for the perpetrators to obtain great benefits in realizing their vision, mission, and goals. Partnerships in education have very broad dimensions, both related to positive and negative goals. In terms of what, how, when, and where educational institutions (education managers) have to collaborate with other parties depending on the complexity, capabilities, and competencies of the leader/manager. The more competent a leader/manager is, the more he will partner and collaborate with both lines within the scope of work, namely staff and employees, as well as within the scope of industrial users or other educational institutions.

While strategic partnerships are defined as long-term cooperation based on mutual trust between partnering institutions and providing benefits to all partner institutions (Hecklau et al., 2016). According to Hanieh et al., (2015) a strong partnership is a partnership based on trust, common goals, honesty, and balance. Good partnership behavior, among others, requires the following conditions: (1) must be loyal to the partnership, prioritizing mutual benefits; (2) respect the different perspectives and organizational cultures of each partner; (3) being generous about the weaknesses that exist in partners, because nothing is perfect; (4) do not have a prejudice against partners. Effective partnership cooperation is a mutually beneficial partnership between parties, by placing both parties in an equal position. In an effective partnership, it must contain the meaning of efforts to fulfill the wishes of each partner and an effective partnership must contain meaning that goes beyond the synergistic meaning (Moeliodihardjo et al., 2012).

There are two contextual understandings of teaching factory management based on partnerships (Alves et al., 2012), namely internally and externally. First, internally it is often used in staff empowerment management terminology, namely a collaboration between managers and staff in managing the organization. In empowerment management, staff are not considered as subordinates but are considered partners in organizational endeavors (Stewart, 1998: 88). Collaboration in Stewart's view is part of the "new management" skills that have not been seen in traditional management. In traditional management there are seven skills/processes for managerial activities, namely planning, communicating, coordinating, motivating (motivating), controlling (controlling), directing (directing), and leading (leading).

It cannot be denied that the skills above, such as planning, communicating, coordinating, and motivating need to be mastered by a manager. However, for the third and last skill, namely controlling, directing, and leading, it is considered no longer effective. According to Stewart, a new set of skills needs to be mastered by the new era managers, namely being able to enable, facilitate, consult, collaborate, mentor, and support.

Second, externally, it is clearly stated in the attachment to Regulation of the Indonesian Minister of National Education Number 19 of 2007 concerning Education Management Standards which states that each 
school establishes partnerships with other relevant institutions, relating to input, process, output, and utilization of graduates. School partnerships can be made with the government and non-government institutions such as universities, equivalent schools, and businesses and industries in their environment. Schools must develop cooperation and partnerships with the community, industry, business, alumni, and other educational units at home and abroad. As an indicator of the quality of the school, operations are to carry out sister school activities. The peak of this success is marked by the implementation of partnership cooperation with schools in countries that excel in the field of education related to improving the quality of graduates so that schools produce quality equal to other superior schools.

In socializing and organizing, partnership and collaboration have a central position because the essence of social and organizational life is an agreement to work together. There is no organization without cooperation. Even in organizational empowerment, cooperation is the ultimate goal of every empowerment program. The success of the manager will be measured by how capable he is to create cooperation within the organization (internal) and establish cooperation with parties outside the organization (external).

\section{METHOD}

This research includes educational research and development (R\&D). Educational research and development is a process carried out to develop and validate educational products (Sekaran \& Bougie, 2016). The use of this design is because Researchers design and validate products in the form of guidelines for the learning process of animation expertise competence based on the needs of the business and industry that will be applied in animation expertise competency vocational schools as an effort to solve problems that have been found. Sugiyono (2015) state procedures in the Research \& Development (R\&D) research method consists of 10 steps, namely (1) Research and information collecting, (2) Planning, (3) Develop a preliminary form of product, (4) Preliminary field testing, (5) Main product revision, (6) Main field testing, (7) Operational product revision, (8) Operational field testing, (9) Final product revision, (10) Dissemination and implementation.

Educational Research becomes the basis for research and development designs where development is complete through the following activities: (1) Potentials and problems; (2) collecting data and information; (3) Designing; (4) Testing; (5) Revision or revision of the initial trial; (6) Main trial by increasing the number of subjects and involving a wider range of stakeholders; (7) Model refinement; (8) Validation test to ensure the readiness of the model to be applied; (9) Revision or improvement and improvement of the final model, and (10) Dissemination and implementation.

The development of a business / industrial competency-based learning management model at animation competency vocational schools through a research and development (R\&D) approach through stages (1) problem identification and information gathering; (2) critical analysis of weaknesses and needs; (3) Describe the factual model; (4) critical analysis of model requirements; (5) Model design; (6) Valuation of the model by experts; (7) Hypothetical model; (8) Focus group discussion (FGD); (9) Evaluation and revision; (10) The final model.

\section{RESULT AND DISCUSSION}

The factual model of animation competency learning management so far at vocational education Raden Umar Said (RUS) was obtained through a preliminary study. Through a preliminary study, information is obtained about the general description, strengths, and weaknesses of the animation learning model so far, which is then used as the basis for the formulation of a competency-based animation learning management model of the business / industrial field in vocational education.

The preliminary research was carried out at vocational education Raden Umar Said (RUS) Kudus from October 2018 - August 2019. Through this research, it can be seen some weaknesses in the animation learning management model that have been around so far, so that solutions can be found through the competency-based animation learning management model of the business/industry field. which has requirements for feasibility, innovativeness, compatibility, and usefulness, for vocational education animation expertise competence in learning management.

The development of a learning management model based on the business and industrial competency in animation competency vocational schools is further analyzed as follows. Through the preliminary study, several weaknesses of the animation learning management model that were studied were found. In the preliminary study, the potential possessed by vocational education RUS was also found. The weaknesses of the learning management model that have been carried out are as follows:

1) Competency standards and basic competence are not in sync with the work competency standards required by business and industry. Such a model causes the graduate competency standard to be incompatible with what is needed in the business and industry. To overcome this problem, in developing a learning management model, competency planning stages are carried out through synchronization with business and industry with the principle of demand and supply. 


\section{2) Partial.}

The management of animation learning in vocational education is still partial to be achieved. Learning like this, besides not being following the principles of the curriculum and management principles, also causes a psychological learning model like this to be felt by students. To overcome this problem, the development of this learning management model is carried out by combining variously defined competencies.

3) Individual teaching.

Learning is carried out individually by each teacher/instructor and is dichotomized between normative, adaptive, and productive teachers. So that the competence to be achieved is fragmented and sometimes the competencies achieved are not interrelated. To overcome this problem, the development of this learning management model is carried out in an organized manner in a departmental working group as team teaching in animation skills competencies consisting of all teachers, instructors from industry, laboratory assistants, and technicians.

The implementation of the animation learning management model is still carried out inconsistently between planning, organizing, implementing, and evaluating. So that the implementation of learning is not based on the syllabus and lesson plans that have been made. This results in the indicators of competency achievement, not following the specified competencies. Management evaluation is carried out every midsemester and at the end of the semester. To overcome this problem, a working group was formed that was tasked with supervising and evaluating the management of learning after each competency was achieved which had been synchronized with business and industry based on a joint plan.

The real condition of the animation competency learning management process still has several weaknesses, such as the less-than-optimal role of business and industry partners, the implementation of learning is not carried out systematically by implementing management functions (planning, organizing, implementing, and evaluating) and the minimal role of stakeholders. On the other hand, the lack of the role of business and industry partners in supporting the implementation of learning is due to several problems, as expressed by the Head of QA/QC and SM-K3 PT. Disney Hollywood and PT. BASE Bali, which includes: 1) lack of information on the implementation of vocational education policies; 2) The lack of an education and training program involving schools, and 3) the limited number of instructors/mentors of students in practice who have insight into educational science.

The success of competency-based learning management in business and industry is largely determined by the principle of supply and demand from all parties in taking on their respective roles. Schools can meet the manpower requirements needed by business and industry with the expected work competencies, while business and industry, apart from receiving a supply of labor with the required competencies, is also a partner in strengthening and developing student competencies. Because of the above principles, the competencies taught in Vocational High Schools must be in sync with the competencies needed in the business and industry.

Ideally, vocational education is built and developed based on the needs of the industrial field, according to Anderson \& Sanga (2019) namely: 1) Effective Vocational Education can only be given if the training task is carried out with the same methods, tools, and machines as those applied in the workplace; 2) Vocational education will be effective if individuals are trained directly and specifically; 3) Fostering effective work habits in students will occur only if the training and learning provided is in the form of real work and not just practice. Based on theoretical studies, the results of relevant research studies, and the problems that arise in the implementation of learning management in animation competence, the factual model is developed into a design model for learning management based on business and industry competencies as the first step in development research as shown in Figure 1. 
EPRA International Journal of Environmental Economics, Commerce and Educational Management Journal DOI: 10.36713/epra0414 |ISI I.F Value: 0.815|SJIF Impact Factor (2020): 7.572

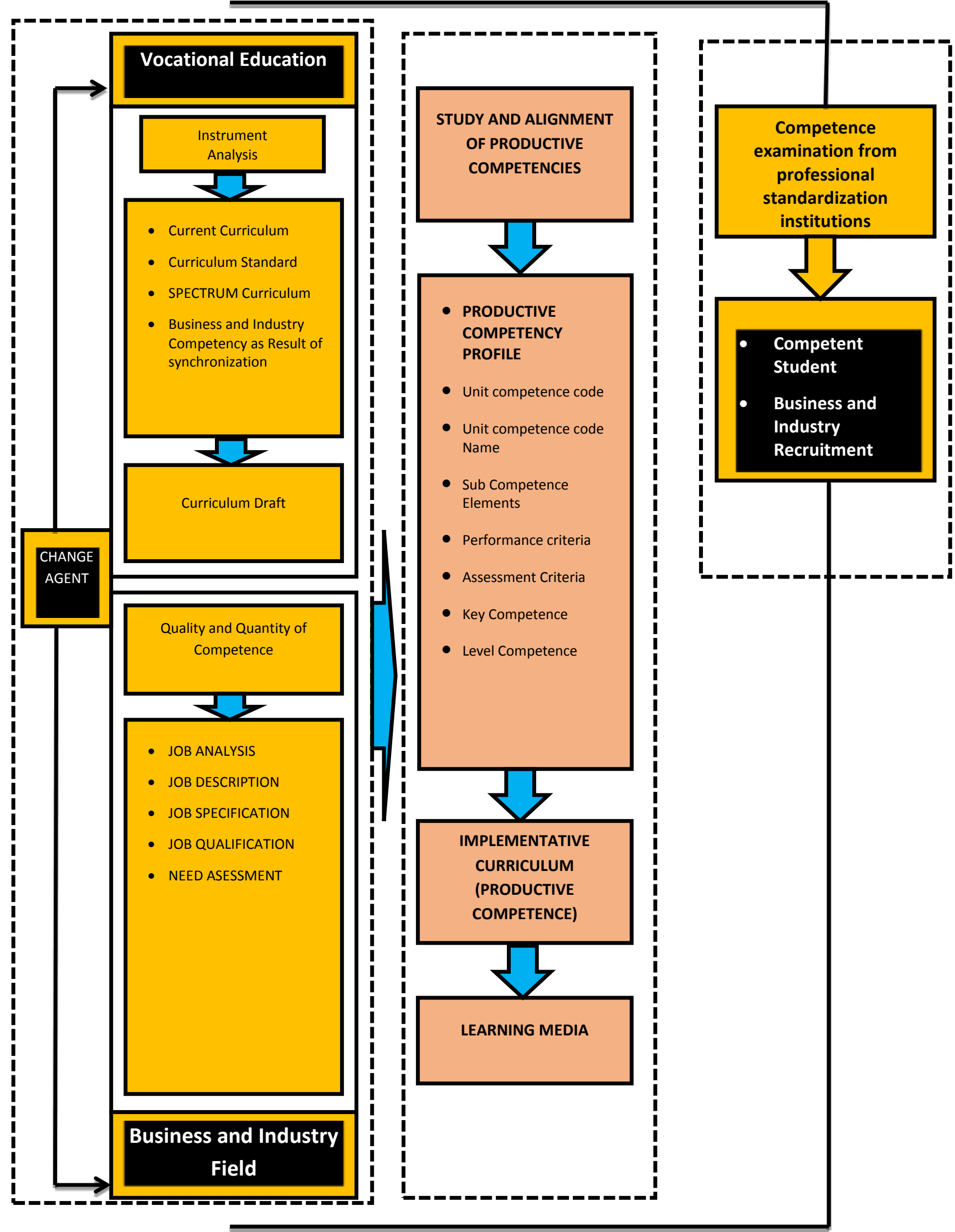

Figure 1. Model to Improve Education Curriculum to Accomodate Business and Indutry Requirements 
A hypothetical model of competency-based learning management business and industry animation expertise program at the development stage is carried out through FGD (Focus Group Discussion) and expert judgment. A hypothetical model of learning management based on business and industrial competencies in animation competency vocational education through FGD (Focus Group Discussion) involving Vocational School Supervisors, Principals, Deputy Principals in the field of curriculum, Deputy Principals in the field of public and industrial relations, the head of expertise competency, laboratory chair, eye teacher animation lessons and business and industry partners.

The FGD (Focus Group Discussion) was held at the vocational education RUS Kudus meeting room. The FGD was conducted through verbal and non-verbal discussions (FGD instrument filling) to obtain input from the design of an animation management model based on business and industry competencies. The aspects used in the FGD refer to Gall, M. D., Gall, J. P., \& Borg (2006), argue that four criteria must be met to assess management model development products which include: utility, feasibility, propriety, and accuracy.

Aspects expected from the benefit criteria include identification of model resources, the credibility of stakeholders, scope of the model (planning, organizing, implementing, and evaluating), accuracy in informing results, and the use of models for competency improvement. The aspects of the feasibility criteria consist of the practicality of the procedure, the linkages between the model components, and the cost-efficiency of the model is implemented. Propriety/politeness has the expected aspects of development model inputs including written agreements/cooperation, conflicts of interest between parties involved in cooperation, dissemination of cooperation, the balance of reporting on cooperation, and responsiveness of cooperation financing. Meanwhile, the aspects of accuracy have parameters including object identification, content analysis, clarity of objectives and procedures, the accuracy of measuring success, and mathematical models. The results of the FGD (Focus Group Discussion) can be described based on the following aspects.

The benefit of developing a learning management model based on business and industrial competencies at vocational education Animation competency through FGD is carried out by assessing aspects that include: identification of model resources, the credibility of stakeholders, the scope of the model, accuracy in informing the results, and competency development Assessment data from 11 respondents on the benefits of learning management based on business and industry competencies at animation competency vocational education through FGD.

\section{CONCLUSION}

The success of competency-based learning management in business and industry is largely determined by the principle of supply and demand from all parties in taking on their respective roles. Schools can meet the manpower requirements needed by business and industry with the expected work competencies, while business and industry, apart from receiving a supply of labor with the required competencies, is also a partner in strengthening and developing student competencies. Because of the above principles, the competencies taught in Vocational High Schools must be in sync with the competencies needed in the business field and industrial field. Incompetency development, this model is very appropriate to be used in vocational schools. The usefulness of the model for the development of competency-based learning for business and industry is expected to further encourage the participation of business and industry in competency synchronization so that vocational education has the same competence or at least synchronize with the business and industrial.

\section{SUGGESTION}

The results of this study can be used as a reference in the development of the curriculum for vocational schools that desire to create an environment that can adapt easily to industry and business. Most vocational schools still use a curriculum that is not based on industrial and business competencies there are can create a gap in the competence of the results of this study. Refers to a model that can be applied therefore vocational-based schools can use and develop this research model. Further research can develop in the field of industrial competence and can improve steps to assess competencies that are following the industrial field.

\section{BIBLIOGRAPHY}

1. Alves, T. D. C. L., Milberg, C., \& Walsh, K. D. (2012). Exploring lean construction practice, research, and education. Engineering, Construction and Architectural Management. https://doi.org/10.1108/09699981211259595

2. Anderson, W., \& Sanga, J. J. (2019). Academia-Industry Partnerships for Hospitality and Tourism Education in Tanzania. Journal of Hospitality and Tourism Education. https://doi.org/10.1080/10963758.2018.1480959

3. Benešová, A., \& Tupa, J. (2017). Requirements for Education and Qualification of People in Industry 4.0. Procedia Manufacturing. https://doi.org/10.1016/j.promfg.2017.07.366

4. Bok, H. G., Teunissen, P. W., Favier, R. P., Rietbroek, N. J., Theyse, L. F., Brommer, H., Haarhuis, J. C., Van Beukelen, P., Van Der Vleuten, C. P., \& Jaarsma, D. A. (2013). Programmatic assessment of competency-based workplace learning: When theory meets practice. BMC Medical Education. https://doi.org/10.1186/1472-6920-13- 
123

5. Brightwell, A., \& Grant, J. (2013). Competency-based training: Who benefits? In Postgraduate Medical Journal. https://doi.org/10.1136/postgradmedj-2012-130881

6. Ford, R., \& Meyer, R. (2015). Competency-based Education 101. Procedia Manufacturing. https://doi.org/10.1016/j.promfg.2015.07.325

7. Fuller, A. (2015). Vocational Education. In International Encyclopedia of the Social \& Behavioral Sciences: Second Edition. https://doi.org/10.1016/B978-0-08-097086-8.92091-9

8. Gall, M. D., Gall, J. P., \& Borg, W. R. (2006). I dentifying a Research Problem and Question, and Searching. Educational Research: An Introduction.

9. Hanafi, I. (2012). Re-Orientasi Keterampilan Kerja. Jurnal Pendidikan Vokasi.

10. Hanieh, A. A., AbdElall, S., Krajnik, P., \& Hasan, A. (2015). Industry-academia partnership for sustainable development in Palestine. Procedia CIRP. https://doi.org/10.1016/j.procir.2014.07.184

11. Hanushek, E. A., Schwerdt, G., Woessmann, L., \& Zhang, L. (2017). General education, vocational education, and labor-market outcomes over the lifecycle. Journal of Human Resources. https://doi.org/10.3368/jhr.52.1.0415$7074 R$

12. Hecklau, F., Galeitzke, M., Flachs, S., \& Kohl, H. (2016). Holistic Approach for Human Resource Management in Industry 4.0. Procedia CIRP. https://doi.org/10.1016/j.procir.2016.05.102

13. Hodge, S. (2007). The origins of competency-based training. Australian Journal of Adult Learning.

14. Koh, G. C. H., Khoo, H. E., Wong, M. L., \& Koh, D. (2008). The effects of problem-based learning during medical school on physician competency: A systematic review. CMAJ. https://doi.org/10.1503/cmaj.070565

15. Moeliodihardjo, B. Y., Soemardi, B. W., Brodjonegoro, S. S., \& Hatakenaka, S. (2012). University, Industry, and Government Partnership: Its Present and Future Challenges in Indonesia. Procedia - Social and Behavioral Sciences. https://doi.org/10.1016/j.sbspro.2012.09.468

16. Morris, M. H., Webb, J. W., Fu, J., \& Singhal, S. (2013). A competency-based perspective on entrepreneurship education: Conceptual and empirical insights. Journal of Small Business Management. https://doi.org/10.1111/jsbm.12023

17. Norjannah, S. (2015). PERATURAN MENTERI RISET, TEKNOLOGI, DAN PENDIDIKAN TINGGI REPUBLIK INDONESIA NOMOR 44 TAHUN 2015. Permenristek.

18. Osler, A. (2011). Teacher interpretations of citizenship education: National identity, cosmopolitan ideals, and political realities. Journal of Curriculum Studies. https://doi.org/10.1080/00220272.2010.503245

19. Raharjo, T. J. (2005). Peran Seni Proses Pembelajaran Pendidikan Luar Sekolah. Harmonia: Jurnal Pengetahuan Dan Pemikiran Seni.

20. Sekaran, U., \& Bougie, R. (2016). Research methods for business : a skill-building approach / Uma Sekaran and Roger Bougie. In Nucleic Acids Research.

21. Sugiyono. (2015). Metode Penelitian \& Pengembangan (Research and Development). Alfabeta.

22. Wardoyo, C. (2015). The Measurement of Teacher's Personality Competence and Performance Using Embedded Model. Journal of Education and Practice.

23. Zhu, C., Wang, D., Cai, Y., \& Engels, N. (2013). What core competencies are related to teachers' innovative teaching? Asia-Pacific Journal of Teacher Education. https://doi.org/10.1080/1359866X.2012.753984

24. Zimmermann, K. F., Biavaschi, C., Eichhorst, W., Giulietti, C., Kendzia, M. J., Muravyev, A., Pieters, J., Rodríguez-Planas, N., \& Schmidl, R. (2013). Youth unemployment and vocational training. Foundations and Trends in Microeconomics. https://doi.org/10.1561/0700000058 